\title{
Regulation of NADPH oxidase (Nox2) by lipid rafts in breast carcinoma cells
}

\author{
RAMA RAO MALLA ${ }^{1}$, HARI RAGHU ${ }^{1}$ and JASTI S. RAO ${ }^{1,2}$ \\ Departments of ${ }^{1}$ Cancer Biology and Pharmacology, and ${ }^{2}$ Neurosurgery, University of \\ Illinois College of Medicine at Peoria, One Illini Drive, Peoria, IL 61605, USA
}

Received June 15, 2010; Accepted July 22, 2010

DOI: 10.3892/ijo_00000801

\begin{abstract}
Oxidative stress has emerged as an important pathogenic factor in the development of breast cancer. Cholesterol-rich membrane rafts or lipid rafts (LRs) are reported to play an important role in oxidative stress-induced signal transduction. NADPH oxidase-dependent reactive oxygen species (ROS) production is implicated in oxidative stress in human mammary epithelial cells. In the present study, we determined the expression and regulation of membranebound subunits by LRs in human breast cancer cells. We report that basal levels of gp91 ${ }^{\text {phox }}$ and $\mathrm{p} 22^{\text {phox }}$ are expressed in breast cancer cells. We demonstrate for the first time that disruption of LRs resulted in the downregulation of NADPH oxidase subunits in breast cancer cells. Cholesterol depletion by $10 \mathrm{mM}$ methyl- $\beta$-cyclodextrin (MBCD) translocated both gp91 phox and $22^{\text {phox }}$ out of LRs. Moreover, lipid raft disruption decreased NADPH oxidase activity $(21.1 \pm 0.5 \%$ in MCF-7 and $28.9 \pm 1.0$ in BT-549 cells), which was reversed by cholesterol repletion $(95 \%)$. Therefore, the results suggest that the integrity of LRs plays an important role in the regulation of NADPH oxidase activity in breast cancer cells.
\end{abstract}

\section{Introduction}

Breast cancer is a devastating disease and is the most frequent malignant cancer diagnosed in females living in developed countries (1). It is the second leading cause of death in women worldwide (2) and comprises $18 \%$ of all female cancers (3). The exact cause or causes of breast cancer remain unknown. Recently, oxidative stress has been implicated as one of the major causes of the pathophysiology of breast cancer (4). However, the precise mechanism of oxidative stress being induced in human breast cancer is poorly understood.

NADPH oxidase, is a multicomponent enzyme complex that contains an integral membrane protein (flavocytochrome

Correspondence to: Dr Jasti S. Rao, Department of Cancer Biology and Pharmacology, University of Illinois College of Medicine, 1 Illini Drive, Peoria, IL 61605, USA

E-mail: jsrao@uic.edu

Key words: NADPH oxidase, ROS, lipid rafts and breast cancer $\mathrm{b}_{558}$ ) and four cytosolic protein components (p67 phox, $\mathrm{p} 47^{\text {phox }}$, p40 phox and small GTPase Rac). Flavocytochrome ${ }^{b} 558$ is a heterodimer composed of a glycosylated subunit, gp91 ${ }^{\text {phox }}$ (also known as Nox2), and non-glycosylated subunit, p22 phox (5). Recent evidence shows that gp91 ${ }^{\text {phox }}$ is the major source of ROS (6), constitutively associates with $\mathrm{p} 22^{\text {phox }}$, and forms a stable catalytic redox center (7). In fact, p22 phox plays a crucial role in the interaction of gp $91^{\text {phox }}$ with cytosolic regulatory subunits via its proline-rich domain (8). p22 phox was also reported to be involved in angiotensin II-mediated generation of ROS in rat smooth muscle cells (9). These finding strongly suggest that both gp $91^{\text {phox }}$ and $\mathrm{p} 22^{\text {phox }}$ are critical components of the NADPH oxidase.

Rafts as signaling platforms in the organization of components in membrane-directed intracellular signaling is widely accepted (10). Lipid rafts are dynamic, detergent-resistant plasma membrane microdomains that are highly enriched in cholesterol and sphingolipids, which have been attributed to function as redox signaling platforms (10). Recently, it has been reported that membrane-bound components of NADPH oxidase are present in LRs, and cytoplasmic components are recruited to raft-associated subunits upon activation and reconstitute the active complex presumably via protein-protein interactions (11). Moreover, distribution and regulation of gp9 $91^{\text {phox }}$ and its regulatory subunits by LRs were also reported in murine microglial, bovine aortic endothelial and bovine coronary arterial endothelial cells (12). However, there are no such studies in breast cancer cells. Cholesterol depletion causes the disorganization of lipid raft microdomains and also the dissociation of raft-bound proteins (13). Cholesterol sequestering agents, like filipin, nystatin or methyl- $\beta$-cyclodextrin (MBCD), remove cholesterol and cause disruption of lipid rafts (14). MßCD is a strictly surface acting agent and can selectively and rapidly remove cholesterol from the raft region of plasma membrane (15). It has been widely used in studying the effects of cholesterol depletion on lipid raft assembly (16). Moreover, MBCD has been reported to possess free radical scavenging activity and to protect against oxidative stress caused by addition of hydrogen peroxide (17).

Therefore, in the present study, we are particularly interested in evaluating the existence of a functional NADPH oxidase system in breast cancer cells and its regulation by lipid rafts. We show here that both gp91 phox and $\mathrm{p} 22^{\text {phox }}$ are localized with lipid rafts and lipid raft disruption using 
Table I. Genes analyzed by reverse transcriptase-PCR.

\begin{tabular}{lll}
\hline Gene & \multicolumn{1}{c}{ Forward primer } & \multicolumn{1}{c}{ Reverse primer } \\
\hline gp91 ${ }^{\text {phox }}$ & 5'-TGGTACACACATCATCTCTTTGTG-3' & 5'-AAAGGGCCCATCAAGCGCTATCTTAGGTAG-3' \\
p22 ${ }^{\text {phox }}$ & 5'-ATGGAGCGCTGGGGACAGAAGTACATG-3' & 5'-GATGGTGCCTCCGATCTGCGGCGG-3' \\
GAPDH & 5'-CGGAGTCAACGGATTTGGTCGTAT-3' & 5'-AGCCTTCTCCATGGTGGTGAAGAC-3' \\
\hline
\end{tabular}

MßCD decreases ROS production in a gp91 phox - and $\mathrm{p} 22^{\text {phox }}$ dependent manner. These observations highlight the fact that lipid raft-associated NADPH oxidases are potentially important therapeutic targets in breast cancer.

\section{Materials and methods}

Cell antibodies and reagents. An LR disruptor, methyl- $\beta-$ cyclodextrin (MßCD), and an antioxidant, N-Acetyl cysteine (NAC), were purchased from Sigma (St. Louis, MO). Antigp91 ${ }^{\text {phox }}$, p22 $2^{\text {phox }}$, flotillin-2 and caveolin-1 were purchased from Santa Cruz Biotechnology (Santa Cruz, CA). Secondary antibodies were also purchased from Santa Cruz Biotechnology.

Detection of reactive oxygen species. 2,7-dichlorofluorescein diacetate (DCFH-DA; Sigma) was used to detect total ROS in MCF-7 and BT-549 cells after treatment with $10 \mathrm{mM}$ $\mathrm{MBCD}$ and $20 \mathrm{mM}$ NAC for $1 \mathrm{~h}$. After treatment, cells were incubated at $37^{\circ} \mathrm{C}$ for 30 min in serum-free medium containing $20 \mathrm{mM}$ DCFH-DA. Then, cells were trypsinized, resuspended in PBS and fluorescence was quantified by spectrofluorimetry (Fluorskam Ascent FL, Milford, MA) using an excitation wavelength of $480 \mathrm{~nm}$ and an emission wavelength of $455 \mathrm{~nm}$. The results are presented as the ratio of the fluorescence of treated samples to that of control samples.

Determination of NADPH oxidase activity. The effect of $\mathrm{MBCD}$ on NADPH oxidase activity was determined using dihydroethidium (DHE) to measure superoxide production. Briefly, cells were grown to $80 \%$ confluence, treated with $10 \mathrm{mM} \mathrm{MBCD}$ and $20 \mathrm{mM}$ NAC for $1 \mathrm{~h}$ and then loaded with $10 \mu \mathrm{M}$ DHE for $40 \mathrm{~min}$. Cells were washed and observed with fluorescence microscopy (Olympus TH4-100, Japan).

Amplex red cholesterol assay. Amplex red cholesterol assay was carried out to determine amount of cholesterol extracted from untreated or MßCD-treated breast cancer cells as per manufacturer's instructions (Sigma). Briefly, MCF-7 and BT549 cells were incubated at $37^{\circ} \mathrm{C}$ with different concentrations of MBCD in DMEM medium for 6 and $24 \mathrm{~h}$. Cholesterol was extracted from the cell lysate by adding $200 \mu \mathrm{l}$ of chloroform and $200 \mu \mathrm{l}$ of methanol to $50 \mu \mathrm{l}$ of sonicated lysate. The bottom cholesterol layer was collected and evaporated under a vacuum. The residual cholesterol was dissolved in $50 \mu \mathrm{l}$ of ethanol, incubated with Amplex Red reagent for $30 \mathrm{~min}$ and fluorescence intensity was measured in a spectrofluorometer using an excitation wavelength in the range of 530-560 nm and emission wavelength of $590 \mathrm{~nm}$. The percentage of reduction of cholesterol was calculated by comparing the fluorescence value of treated and untreated cells.
BrdU cell proliferation assay. BrdU cell proliferation assay was carried out to determine the cytotoxic effect of MßCD on MCF-7 and BT-549 cells according to the manufacturer's instructions (Roche Applied Science, Branford, CT). In brief, target cells $\left(1 \times 10^{4}\right)$ in 96-well plates were treated with 5, 7.5 and $10 \mathrm{mM}$ concentrations of MBCD for $6,12,24$ and $48 \mathrm{~h}$. BrdU labeling solution $(200 \mu \mathrm{l})$ was added to each well and incubated for $12 \mathrm{~h}$. Then cells were fixed, permeabilized and the DNA was denatured by treatment with fixative/denaturing solution. Detector horseradish peroxidase-conjugated BrdU anti-mouse antibody $(100 \mu \mathrm{l})$ was added to each well and incubated for $1.5 \mathrm{~h}$. Unbound antibody was washed with PBS, $100 \mu 1$ of substrate solution was added, and cells were incubated at $37^{\circ} \mathrm{C}$ for $30 \mathrm{~min}$. The blue fluorescence produced was quantified using a microplate reader (BioRad Systems, Philadelphia, PA) at $370 \mathrm{~nm}$ (reference wavelength: $492 \mathrm{~nm}$ ), and results were expressed as percent of inhibition of cell proliferation as compared to the controls.

Reverse transcription PCR. Total RNA was isolated from MCF-7 and BT-549 cells in all treatment conditions using TRIzol reagent (Invitrogen, Carlsbad, CA). DNase-treated RNA was used as a template for reverse transcription (RT) reaction (Invitrogen) followed by PCR analysis using primers specific for gp91 ${ }^{\text {phox }}, \mathrm{p} 22^{\text {phox }}$ and GAPDH. The PCR conditions were as follows: $94^{\circ} \mathrm{C}$ for $5 \mathrm{~min}$, followed by 35 cycles of $94^{\circ} \mathrm{C}$ for $30 \mathrm{sec}, 58^{\circ} \mathrm{C}$ for $45 \mathrm{sec}$ and $72^{\circ} \mathrm{C}$ for $45 \mathrm{sec}$. GAPDH was used as an internal control (Table I).

Western blotting. Untreated or MBCD-treated MCF-7 and BT-549 cells were harvested and homogenized in lysis buffer and processed for cell lysates. Equal amounts of cellular proteins were subjected to SDS-PAGE using appropriate percentage of acrylamide gels. After separation, proteins were transferred onto nitrocellulose membrane and blocked in 5\% dry non-fat milk in PBS-T (PBS containing 0.05\% Tween) for $1 \mathrm{~h}$. The membrane was incubated with agitation in primary antibodies against gp91 ${ }^{\text {phox }}$ and $\mathrm{p} 22^{\text {phox }}$ (Santa Cruz Biotechnology) at $4^{\circ} \mathrm{C}$. To confirm equal protein loading, blots were also probed with anti-mouse GAPDH antibody. After three washes in PBS-T, the membrane was incubated with horseradish peroxidase-conjugated secondary antibodies for $1 \mathrm{~h}$ at room temperature. After, washing bands were developed by an enhanced chemiluminescence reaction (Amersham Biosciences, Piscataway, NJ), quantified by densitometric analysis (Image $\mathbf{J}$ software), and expressed as a percentage of the controls.

Co-localization studies of gp91 phox and p22phox with lipid raft markers. MCF-7 and BT-549 cells were grown to $80 \%$ 
confluence in 8-well chamber slides and left untreated or treated with $10 \mathrm{mM} \mathrm{MBCD}$ for $1 \mathrm{~h}$ at $37^{\circ} \mathrm{C}$. After treatment, cells were fixed with $2 \%$ paraformaldehyde and permeabilized with $0.5 \%$ Triton X-100. Then, cells were blocked with $5 \%$ BSA in PBS and incubated overnight with anti-goat gp91 phox, anti-rabbit $\mathrm{p} 22^{\text {phox }}$, anti-mouse flotillin or anti-mouse caveolin primary antibodies at $4^{\circ} \mathrm{C}$. After washing, cells were incubated with secondary anti-mouse Alexa Fluor-594 and anti-rabbit/ anti-goat Alexa Fluor-488 antibodies for $1 \mathrm{~h}$ at room temperature. Finally, cells were washed with PBS, mounted with anti-fading agent containing DAPI, and examined under a confocal fluorescence microscope.

Biochemical isolation of lipid rafts. MCF-7 and BT-549 cells $\left(2-3 \times 10^{7}\right.$ cells $)$ were serum-starved overnight and then left untreated or treated with $10 \mathrm{mM} \mathrm{MBCD}$ for $24 \mathrm{~h}$ at $37^{\circ} \mathrm{C}$. Adherent cells were washed with PBS, lysed with extraction buffer as per manufacturer's instructions (Sigma). The cell lysates were mixed with OptiPrep ${ }^{\circledR}$ density gradient medium (final concentration, $35 \% \mathrm{v} / \mathrm{v}$ ), and placed at the bottom of a $12-\mathrm{ml}$ ultracentrifuge tube. A discontinuous Optiprep gradient was prepared by overlaying $2 \mathrm{ml}$ of 30,25 and 20\% Optiprep (prepared by diluting OptiPrep in extraction buffer) and ultracentrifuged at 100,000 x g for $4 \mathrm{~h}$. Fractions were collected and analyzed by Western blotting. Fractions 2, 3, 4 were marked as raft fractions and fractions 6, 7, 8 were labeled as non-raft fractions based on the specificity to flotillin and transferrin in MCF-7 cells and caveolin and transferrin in BT-549 cells, respectively.

Cholesterol supplementation experiments. Cells were treated with $10 \mathrm{mM} \mathrm{MBCD}$ for $24 \mathrm{~h}$ and further incubated for $24 \mathrm{~h}$ with or without $2 \mathrm{M}$ cholesterol MßCD complexes. Cells were harvested, homogenized in lysis buffer. Western blotting was carried out as described above. After treatment with cholesterol MBCD complexes, total ROS levels were measured as described above. Immunofluorescence assay was carried out to determine the co-localization of gp91phox and $\mathrm{p} 22^{\text {phox }}$ with raft markers after treatment with cholesterol MBCD complexes.

Data analysis. Data are presented as means \pm SE of three independent experiments. Densitometric quantification was performed using Image J software for Windows. Statistical analysis was performed by means of Student's t-test; $\mathrm{p}<0.05$ was considered statistically significant.

\section{Results}

Localization of lipid rafts in MCF-7 and BT-549 cells. As an initial approach, laser scanning confocal microscopy was used to examine the localization of lipid rafts in the plasma membrane of MCF-7 and BT-549 cells (data not shown). Raft marker flotillin-2 was found in MCF-7 and caveolin-1 was found in BT-549 breast cancer cells.

Total reactive oxygen species (ROS). Lipid rafts depend critically on cholesterol and are disrupted by cholesterol depletion. To investigate the role of LRs in the regulation of ROS generation from NADPH oxidase, we used a cholesterol- depleting agent (MßCD) to disrupt LRs. The effect of MßCD on ROS production is shown in Fig. 1A. MßCD decreased ROS by 21 and 29\% in MCF-7 and BT-549, respectively. Similarly, a known antioxidant, $\mathrm{N}$-acetyl cysteine, reduced ROS by $19 \%$ in MCF-7 cells and $27 \%$ in BT-549 cells. However, a known inhibitor of NADPH oxidase, diphenyleneiodonium (DPI; Sigma) decreased total ROS by 35 and $31 \%$ in MCF-7 and BT-549 cells, respectively.

NADPH oxidase activity. The DCF-DA assay is a measure of total ROS rather than a direct assay of any one particular ROS species. Therefore, an assay specific for detection of NADPH oxidase activity in terms of superoxide generation was utilized. Dihydroethidium (DHE) is a fluorescent probe specifically oxidized by superoxide and its fluorescence was used to determine the effect of MßCD on intracellular superoxide generation. MBCD decreased superoxide production as demonstrated by a decrease in ethidium fluorescence when compared to the control as well as a positive control, $\mathrm{N}$-acetyl cysteine (Fig. 1B and C). Taken together, these results suggest that NADPH oxidase is regulated by lipid rafts.

Effect of enzyme inhibitors on generation of superoxide. To rule out other sources of superoxide, breast cancer cells were also treated with apocynin (a specific inhibitor of NADPH oxidase), rotenone (mitochondria electron transport inhibitor), oxypurinol (xanthine oxidase inhibitor), L-NAME (nitric oxide synthase) or MßCD for $1 \mathrm{~h}$ and then stained with DHE. Fluorescence was measured on excitation at $488 \mathrm{~nm}$ and emission at $610 \mathrm{~nm}$. Only MBCD and APC decreased ROS; other inhibitors failed to decrease ROS. These results suggest that NADPH oxidase is the primary source of intracellular ROS generation (Fig. 1D).

Depletion of membrane cholesterol. Sterols play a crucial regulatory and structural role in the lateral organization of eukaryotic cell membranes. Cholesterol has been connected to the possible formation of ordered lipid domains (rafts) in mammalian cell membranes. Cholesterol and sphingomyelin are thought to be the principal components of lipid rafts in cell and model membranes (18). To deplete MCF-7 and BT549 cells of cholesterol to levels that affected NADPH oxidase activity, cells were treated with 5.0, 7.5 and $10 \mathrm{mM} \mathrm{MBCD}$ for 6 and $24 \mathrm{~h}$. As shown in Fig. 2A and B, $10 \mathrm{mM} \mathrm{MBCD}$ removed 47.2 and $23.3 \%$ of total cholesterol in MCF-7 and BT-549 cells, respectively, in $24 \mathrm{~h}$. Moreover, extraction of cholesterol in both MCF-7 and BT549 cells occurred in a concentration-dependent manner, which is similar to other reports (19).

Cytotoxic effect of M $\beta C D$ on MCF-7 and BT-549 cells. $\mathrm{M} B C D$ is widely used to disrupt lipid rafts and is the focus of drug development. The toxicity is reported to be varied and dependent on the cell type and the concentration used. We evaluated the potential toxicity of MBCD using the BrdU cell proliferation assay. We first exposed MCF-7 and BT-549 cells to various concentrations of MBCD for 6, 12, 24 and $48 \mathrm{~h}$ to determine the dose response. After $24 \mathrm{~h}, 10 \mathrm{mM} \mathrm{MBCD}$ caused $22 \%$ growth inhibition in MCF-7 cells and $29 \%$ in BT-549 cells (Fig. 2C and D). However, at 48 h, there was a 
A)

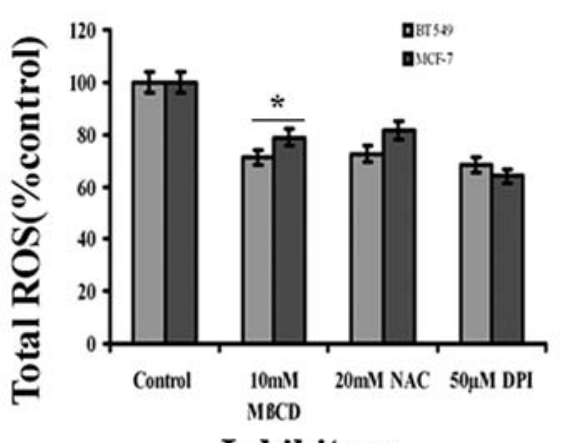

Inhibitors
D)

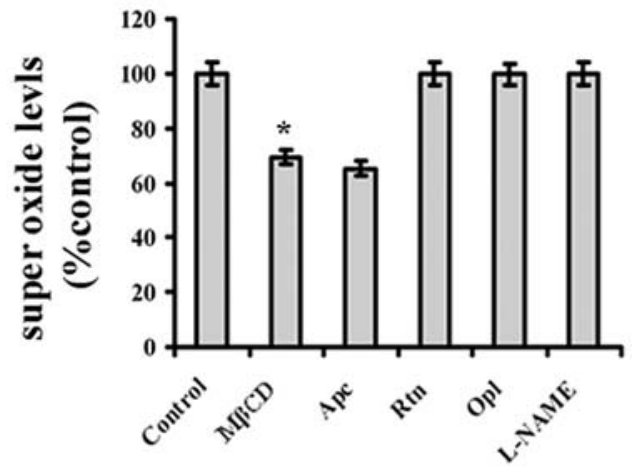

Inhibitors
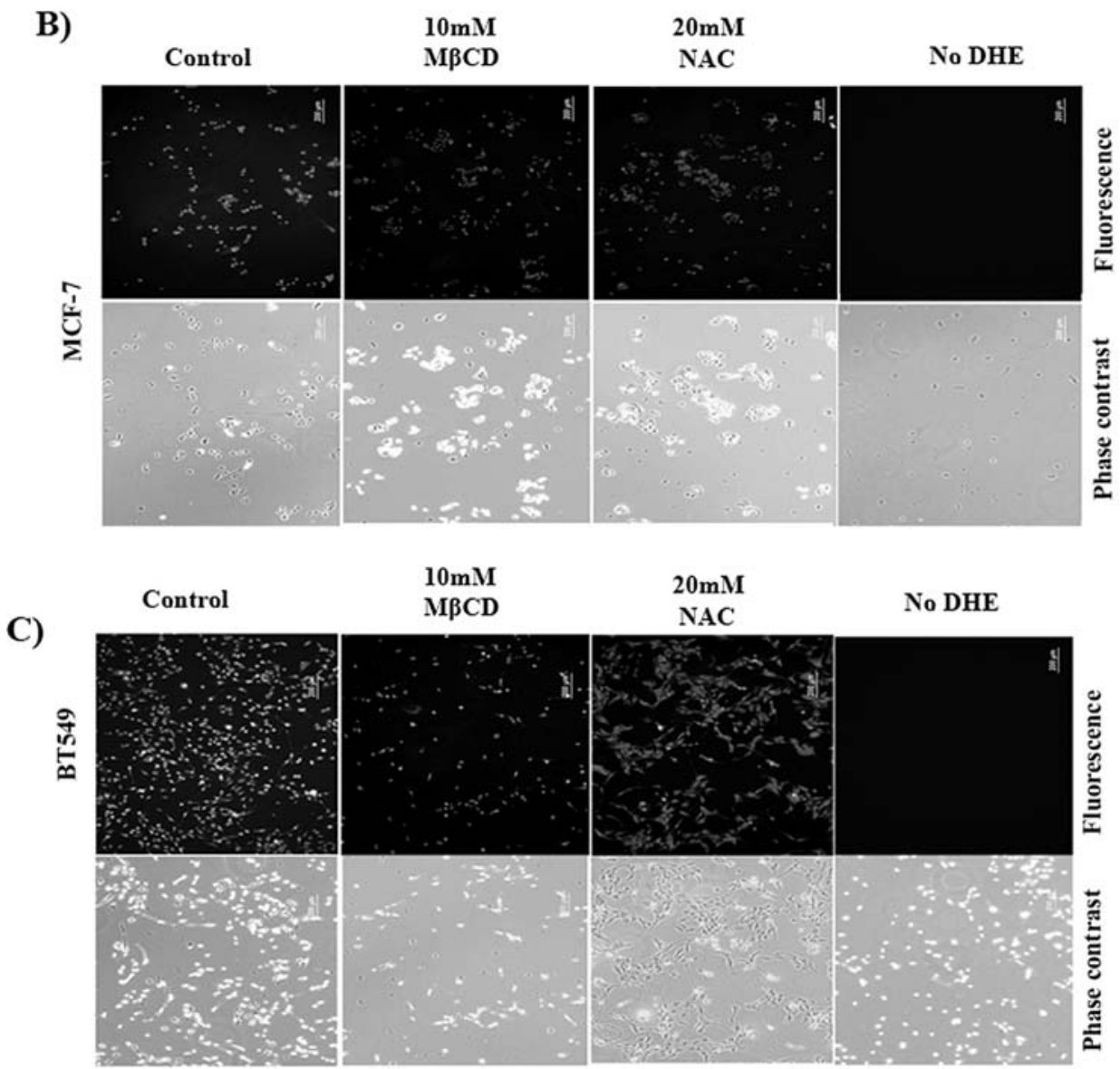

Figure 1. Effect of MBCD on ROS generation in MCF-7 and BT-549 breast cancer cells. (A) Effect of MBCD on total reactive oxygen species in MCF-7 and BT-549 cells. MCF-7 and BT-549 cells were treated with MBCD for $1 \mathrm{~h}$ and loaded with DCFH-DA and relative fluorescence was measured after 30 min. DPI was used as a positive control (mean \pm SD; $n=3 ;{ }^{*}$ p $<0.05$ ). Effect of MBCD on NADPH oxidase activity in (B) MCF-7 and (C) BT-549 cells. MCF-7 and BT-549 cells were treated with MBCD for $1 \mathrm{~h}$ and loaded with DHE and observed for intracellular superoxide generation by fluorescence microscopy after 40 min. N-Acetyl cysteine was used as positive control ( $\mathrm{n}=3$ ). (D) Effect of enzyme inhibitors on generation of superoxide. MCF-7 and BT-549 cells were treated with apocynin (a specific inhibitor of NADPH oxidase), rotenone (mitochondria electron transport inhibitor), oxypurinol (xanthine oxidase inhibitor) L-NAME (nitric oxide synthase) or MBCD for $1 \mathrm{~h}$ and stained with DHE. Fluorescence was measured on excitation at $488 \mathrm{~nm}$ and emission at $610 \mathrm{~nm}$. The values were expressed as mean \pm SD for three independent experiments (Apc, apocynin; Rtn, rotenone; Opl, oxypurinol).

significant loss of cell viability in both MCF-7 (34\%) and BT-549 (42\%) cells.

Expression of NADPH oxidase in MCF-7 and BT-549 cells. To determine whether NADPH oxidase is regulated by lipid rafts, we examined the expression of membrane-bound subunits of NADPH oxidase at the mRNA level after treatment with $10 \mathrm{mM} \mathrm{MßCD}$ for 6 and $24 \mathrm{~h}$. Fig. 3A-C shows that expression of gp91 $91^{\text {phox }}$ was downregulated to $82 \%$ in MCF-7 cells and $85 \%$ in BT-549 cells at $24 \mathrm{~h}$. In addition, p22 phox 
A)

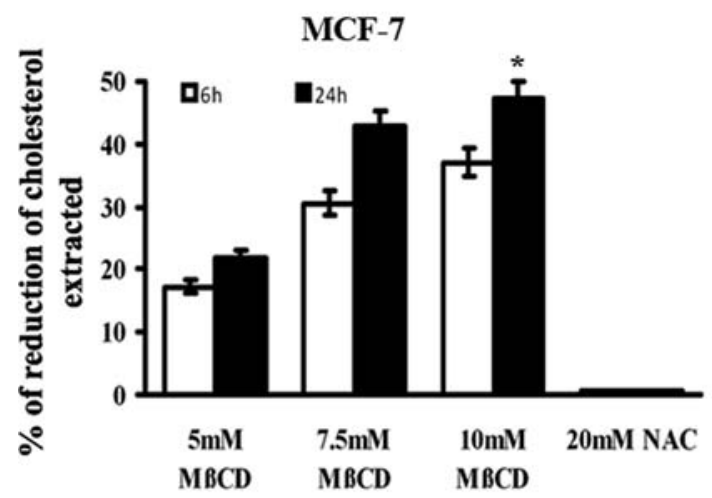

C)

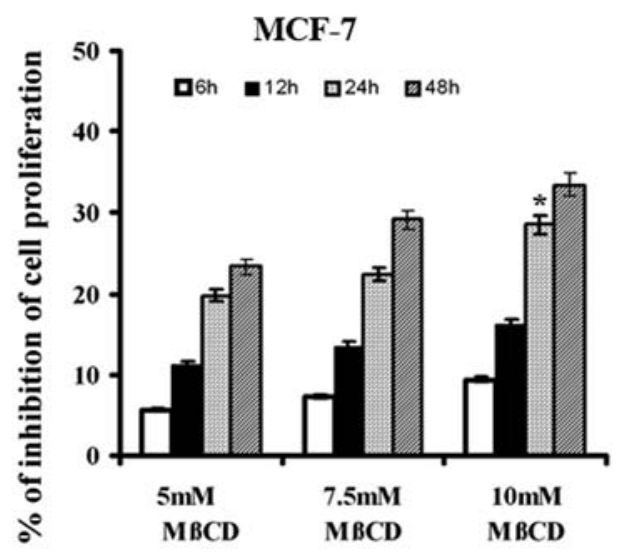

B)

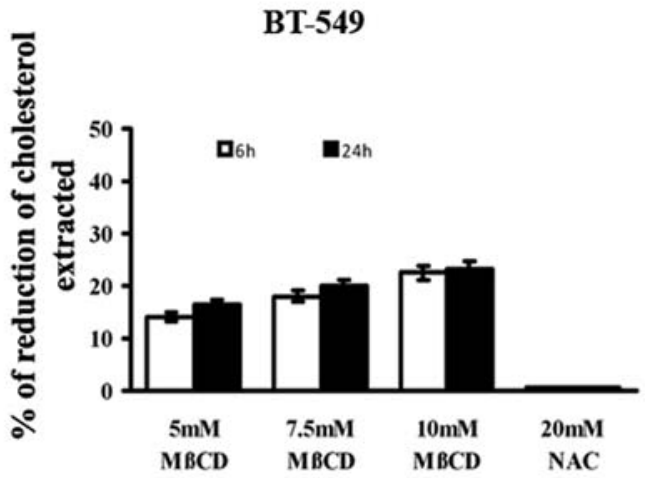

D)

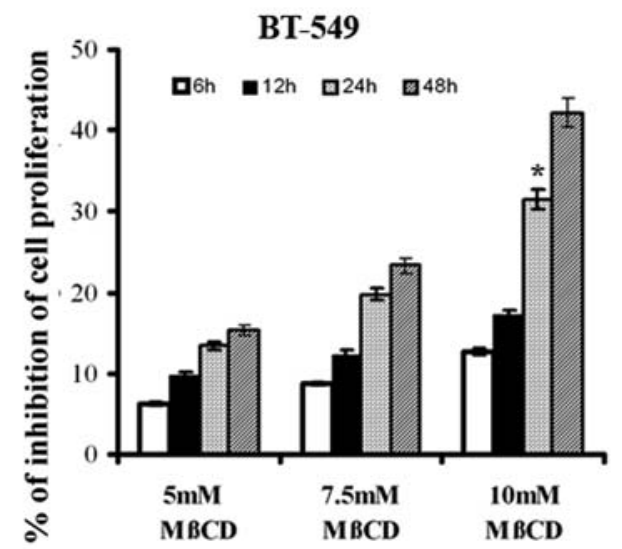

Figure 2. Effect of MBCD on membrane cholesterol and cell viability. MCF-7 and BT-549 cells were treated with different concentrations of MBCD for $1 \mathrm{~h}$, and cholesterol levels were measured at 6 and $24 \mathrm{~h}$ in (A) MCF-7 and (B) BT-549 cells. The percent reduction in the cholesterol upon the drug treatment was calculated with respect to total cholesterol in the untreated cells, which was taken as $100 \%$. The results represent the mean \pm SD of three independent experiments $\left({ }^{*} \mathrm{p}<0.05\right)$. Dose- and time-dependent effect of MBCD on cell viability. MCF-7 and BT-549 cells were treated with different concentrations of MBCD for 6, 12, 24 and $48 \mathrm{~h}$ and percent of inhibition of cell proliferation was measured by BrdU incorporation assay in (C) MCF-7 and (D) BT-549 cells. The results represent the mean $\pm \mathrm{SD}$ of three independent experiments $\left({ }^{*} \mathrm{p}<0.05\right)$.

was significantly downregulated by $85 \%$ in MCF-7 cells and $80 \%$ in BT-549 cells after treatment with MßCD for $24 \mathrm{~h}$ (Fig. 3D-F). We also attempted to confirm the regulation of NADPH oxidase subunits by lipid rafts in MCF-7 and BT549 cells using an independent line of evidence. To this end, we screened membrane-soluble homogenate $(25,000 \mathrm{x} \mathrm{g}$ supernatant) obtained at 6 and $24 \mathrm{~h}$ after treatment with MBCD. We performed Western blot analysis using gp91 phox and $\mathrm{p} 22^{\text {phox }}$ polyclonal antibodies. The expression of gp91 ${ }^{\text {phox }}$ and p22phox is depicted in Fig. 4A-D. The results show that gp91 ${ }^{\text {phox }}$ significantly decreased in MCF-7 (61\%) and BT-549 (78\%) cells (Fig. 4E) whereas p22 phox significantly decreased in MCF-7 (90\%) and BT-549 (95\%) cells (Fig. 4F).

Association of lipid rafts with gp91 ${ }^{\text {phox }}$ and $p 22^{\text {phox }}$ in MCF-7 and BT-549 cells. The size of lipid rafts is $<100 \mathrm{~nm}$ (20), which falls below the resolution of light microscopic techniques. However, antibody mediated co-localization of cell surface antigen has previously been used to demonstrate raft association (18). Under resting conditions (untreated), there were a number of yellow areas (e.g., dots or patches) resulting from the merging of two sequentially scanned images obtained at different wavelengths. These yellow patches are considered evidence of co-localization of LR and gp91 phox in MCF-7 and BT-549 cells. When the cells were pretreated with MBCD, we no longer observed the yellow patches (Fig. 5A and B). We also carried out similar experiments using a p22 phox antibody; we observed a similar distribution pattern to gp91 ${ }^{\text {phox }}$ (Fig. 5C and D) both in MCF-7 and BT-549 cells.

Effect of cholesterol supplementation on NADPH oxidase. Previously, we have shown that cholesterol depletion by 
A)

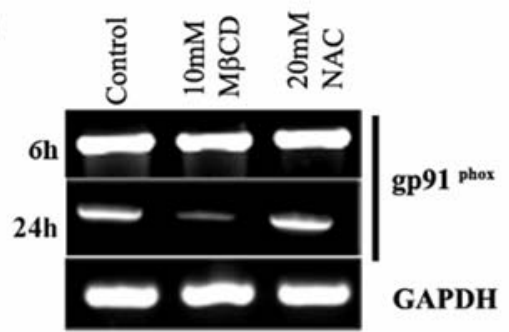

B)

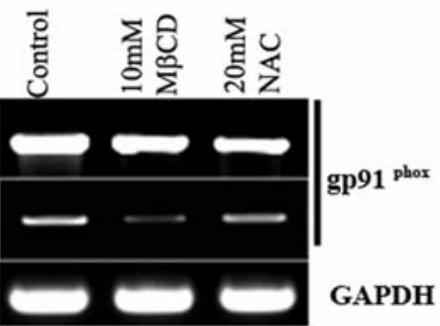

C)

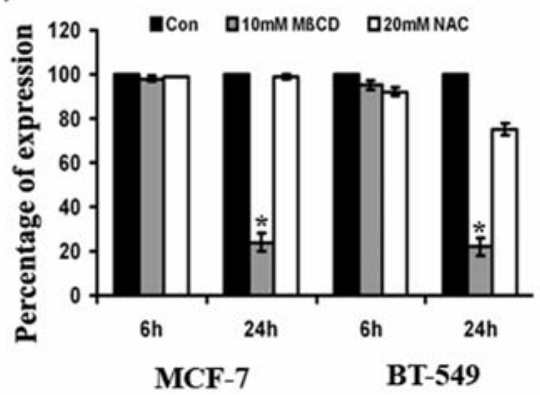

D)

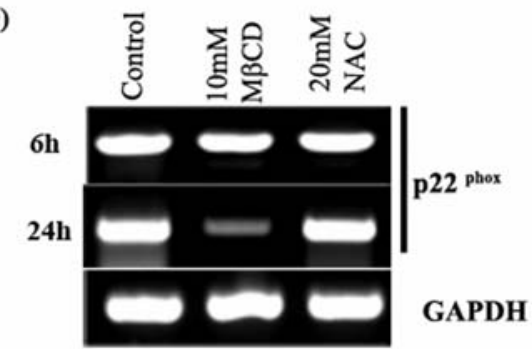

E)

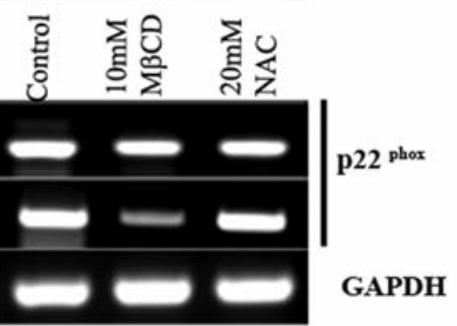

F)

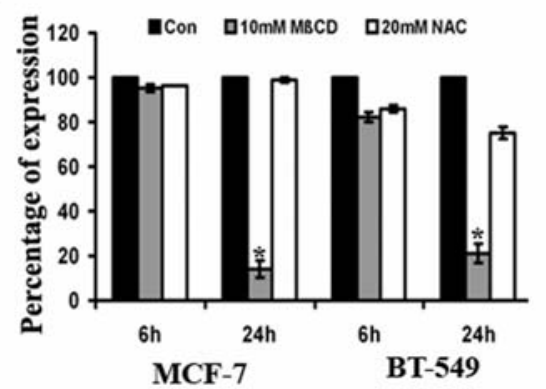

Figure 3. Expression of gp9 $1^{\text {phox }}$ and p22 $2^{\text {phox }}$ mRNAs in MCF-7 and BT-549 cells. mRNA expression of gp91 phox in (A) MCF-7 and (B) BT-549 cells and p22 $2^{\text {phox }}$ in (D) MCF-7 and (E) BT-549 cells was determined. Expression was normalized to GAPDH and semi-quantified by RT-PCR in untreated (control) and MBCD-treated MCF-7 and BT-549 cells. The values are expressed as a percent of mRNA expression, relative to the control, which was set at 100\%. (C) Densitometric analysis of gp91 ${ }^{\text {phox }} \mathrm{mRNA}$ expression in MCF-7 and BT-549 cells. (F) Densitometric analysis of p22 ${ }^{\text {phox }} \mathrm{mRNA}$ expression in MCF-7 and BT549 cells. The error bars represent mean $\pm \mathrm{SD}$ of three independent experiments $\left({ }^{*} \mathrm{p}<0.05\right)$.

A)

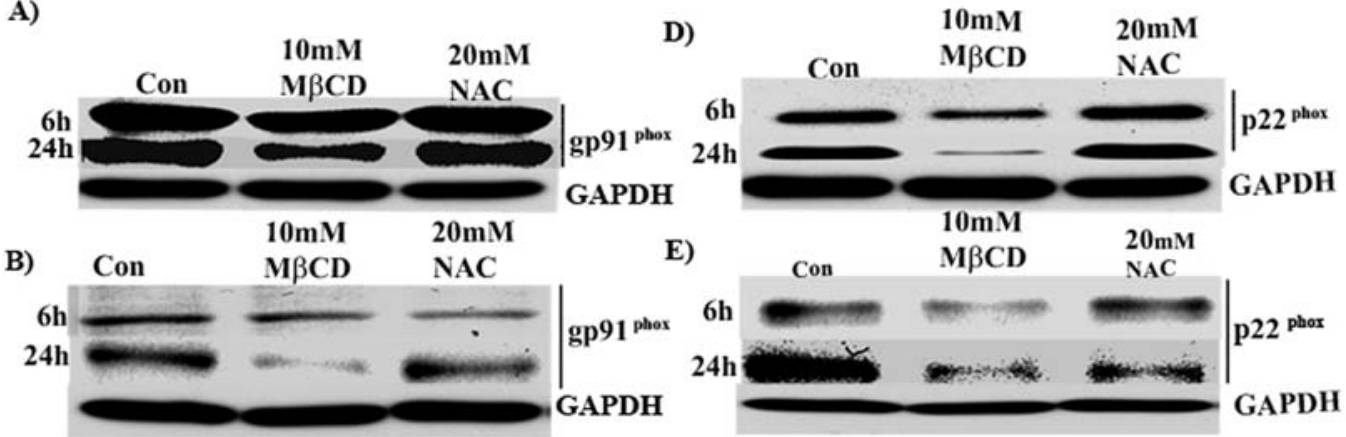

C)

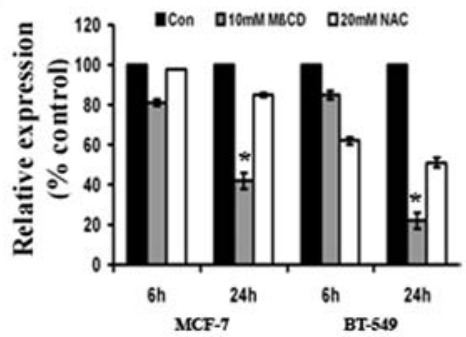

F)

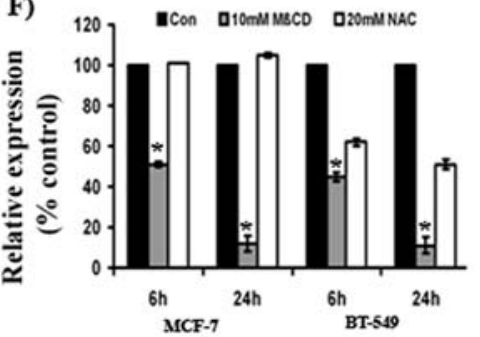

Figure 4. Expression of gp91 $91^{\text {phox }}$ and p22 $2^{\text {phox }}$ proteins in MCF-7 and BT-549 cells. Western blots were performed to determine protein expression. GAPDH served as a loading control. Protein expression of gp9 $1^{\text {phox }}$ in (A) MCF-7 and (B) BT-549 cells and p22 phox in (D) MCF-7 and (E) BT-549 cells was determined. (C) Densitometric analysis of gp9 $91^{\text {phox }}$ protein expression in MCF-7 and BT-549 cells. (F) Densitometric analysis of p22 $2^{\text {phox }}$ protein expression in MCF-7 and BT-549 cells. Results are representative of three independent experiments $\left({ }^{*} \mathrm{p}<0.05\right)$. 
A)
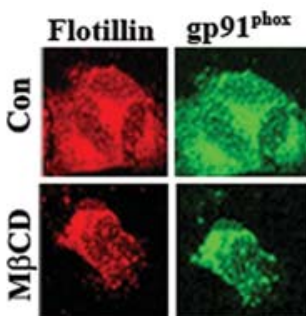

B)
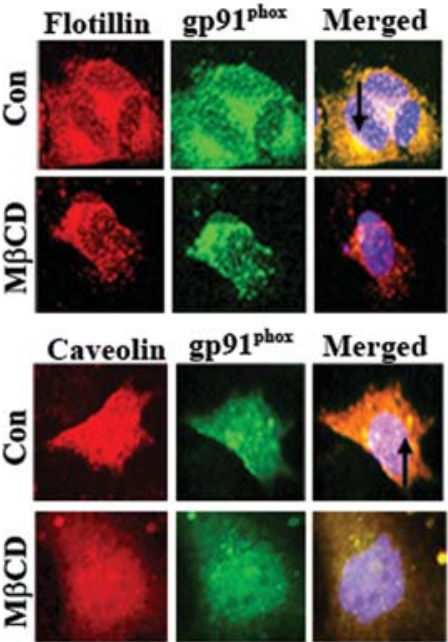

C)
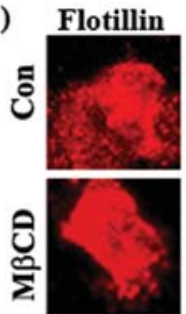

D) Caveolin
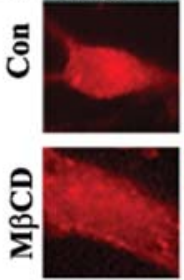
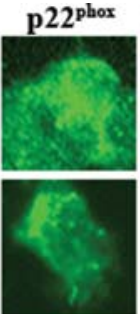

p22 $2^{\text {phox }}$

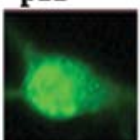

Merged

Merged
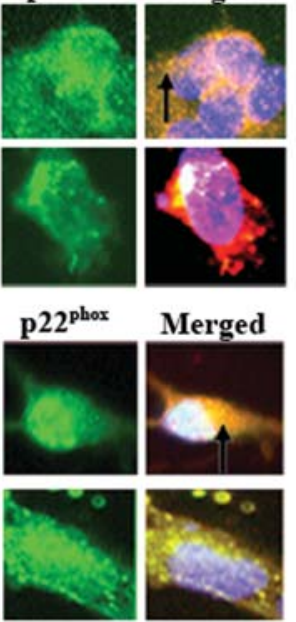

E)
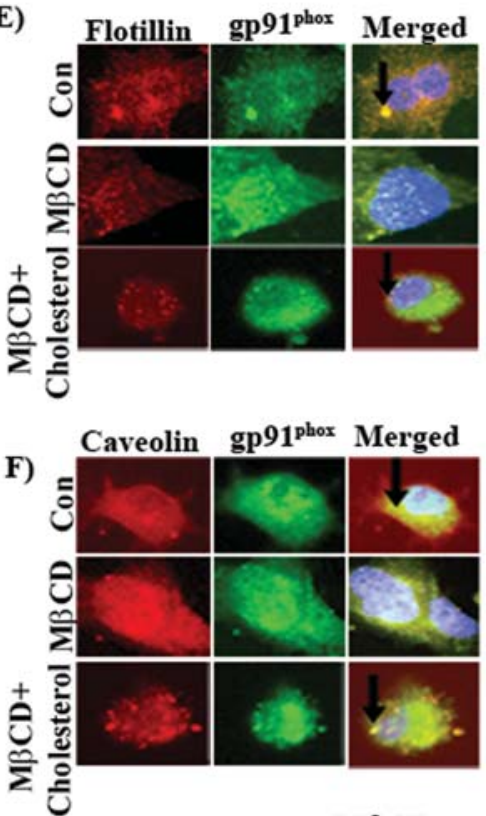

gp91 ${ }^{\text {phox }}$ Merged

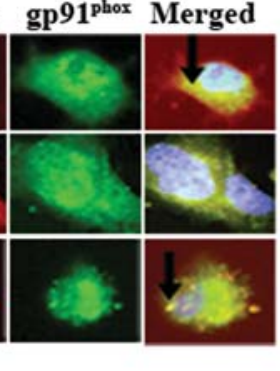

M $\beta$ CD+

I)

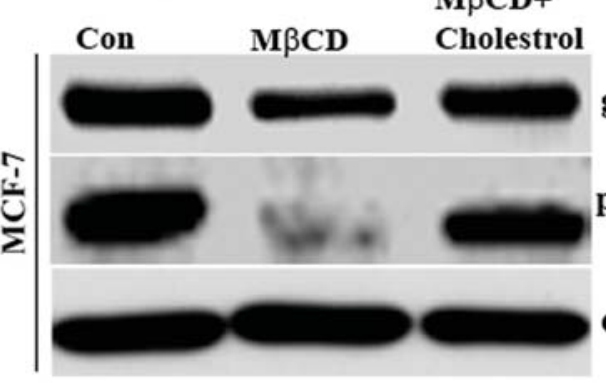

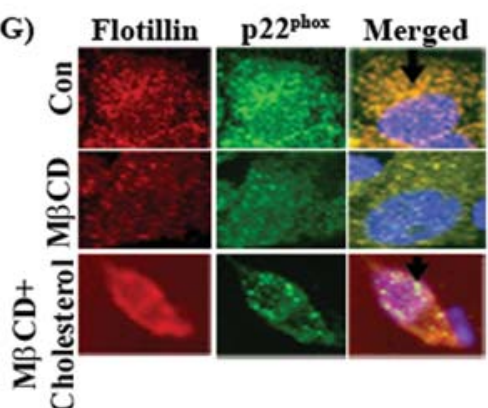

H) Caveolin p22 ${ }^{\text {phox }}$ Merged

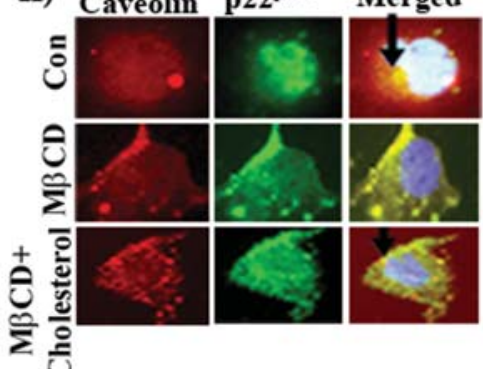

J)

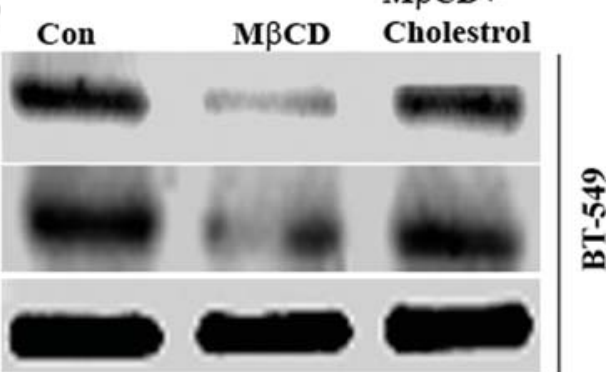

Figure 5. Co-localization of gp91 phox and p22phox with lipid rafts in MCF-7 and BT-549 breast cancer cells. Co-localization of gp91 phox with flotillin-2 in (A) MCF-7 cells and with caveolin-1 in (B) BT-549 cells. Co-localization of p22 phox with flotillin-2 in (C) MCF-7 and with caveolin-1 in (D) BT-549 cells. (E) Co-localization of gp91phox with flotillin in MCF-7 cells treated with MBCD and supplemented with cholesterol. (F) Co-localization of gp91 phox with caveolin in BT-549 cells treated with MBCD and supplemented with cholesterol. (G) Co-localization of p22 phox with flotillin in MCF-7 cells MBCD-treated and cholesterol-supplemented. (H) Co-localization of p22 $2^{\text {phox }}$ with caveolin in BT-549 cells treated with MBCD and supplemented with cholesterol. For colocalization studies, MCF-7 and BT-549 cells were grown in 8-well chamber slides, serum-starved overnight, and then either left untreated or treated either with $10 \mathrm{mM} \mathrm{MBCD}$ or $10 \mathrm{mM}$ MBCD and cholesterol complex. Cells were washed, fixed, permeabilized and blocked with $5 \%$ BSA for $30 \mathrm{~min}$. These cells were washed and labeled with anti-goat gp $91^{\text {phox }}$, anti-rabbit $\mathrm{p} 22^{\text {phox }}$, anti-mouse flotillin or anti-mouse caveolin primary antibodies and left at $4^{\circ} \mathrm{C}$ overnight. The cells were further incubated with secondary anti-mouse Alexa Fluor-594, anti-rabbit or anti-goat Alexa Fluor-488 antibodies for $1 \mathrm{~h}$ at room temperature. Finally, cells were washed with PBS and mounted with anti-fading agent containing DAPI and examined under a fluorescence microscope. Co-localization of NADPH oxidase subunits and lipid rafts is shown with arrows in the merged panels. Green represents either gp91 phox or p22 $2^{\text {phox }}$ and red represents either flotillin or caveolin; yellow or orange represents co-localization. (I) Expression of gp91 phox protein in MCF-7 and BT-549 cells treated with MBCD and supplemented with cholesterol. (J) Expression of p22 phox protein in MCF-7 and BT-549 cells treated with MBCD and supplemented with cholesterol. The values are expressed as means $\pm \mathrm{SD}$ of three independent experiments. 
A)

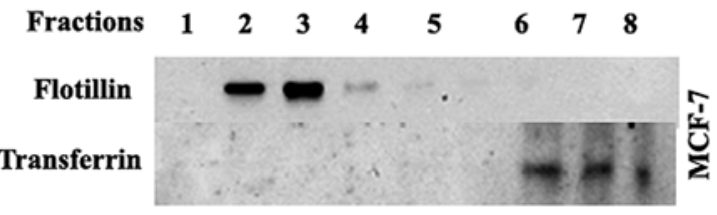

C)

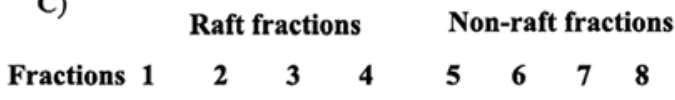

B)

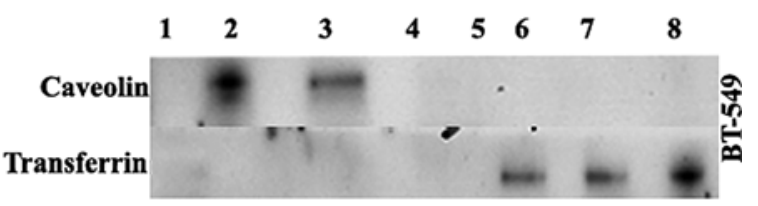

D)

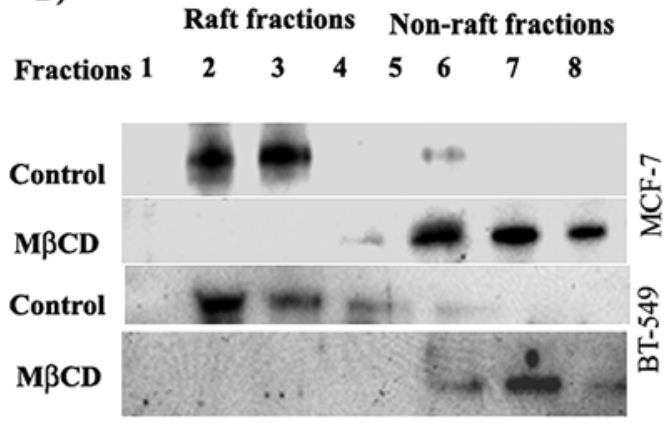

Figure 6. Optiprep gradient analysis of LR marker proteins for gp91 phox and p22 phox subunits of NADPH oxidase. Proteins from Optiprep gradient fractions (1-8) were immunoblotted with indicated antibodies as described in Materials and methods. Expression of flotillin and transferrin in (A) MCF-7 cells and caveolin and transferrin in (B) BT-549 cells. Fractions 2-4 are LR fractions and 5-8 are non-LR fractions. Proteins (40 $\mu \mathrm{g}$ per lane) from the gradient fractions were probed with antibodies against gp91 phox and p22 phox. The distribution of gp91 phox in (C) MCF-7 and BT-549 cells and p22 phox in (D) MCF-7 and BT-549 cells. A representative immunoblot of three separate experiments is shown.

MBCD decreased NADPH oxidase activity and expression at both protein and mRNA levels. To assess whether the effect of MßCD on NADPH oxidase is permanent or reversible, exogenous cholesterol was used to replenish the reduced level of lipid rafts-associated cholesterol in MßCD-treated breast cancer cells. In this experiment, both MCF-7 and BT549 cells were pretreated with MBCD for $24 \mathrm{~h}$ and then supplemented with or without MBCD cholesterol complex for $24 \mathrm{~h}$. We used laser-scanned confocal microscopy to analyze the expression of gp91 $91^{\text {phox }}$ and $\mathrm{p} 22^{\text {phox }}$ in cells treated with $\mathrm{MBCD}$ and cholesterol, $\mathrm{M} B \mathrm{CD}$ alone and no treatment. The images demonstrated that yellow dots or patches were present in untreated cells, but absent in MBCD-treated cells. Notably, these patches returned in MCF-7 and BT-549 cells when MBCD treatment was followed by cholesterol supplementation (Fig. 5E-H). Lysates were prepared and subjected to immunoblotting analysis. Expression of gp91 phox and p22 phox was reversed by $90-95 \%$ with cholesterol supplementation (Fig. 5I and J). These results indicate that the gp91 phox and p22 phox subunits of NADPH oxidase mainly associate with lipid rafts.

Biochemical analysis of lipid raft fractions for gp91phox and $p 22^{\text {phox }}$. In previous experiments, gp $91^{\text {phox }}$ and $\mathrm{p} 22^{\text {phox }}$ were co-localized with lipid raft markers flotillin or caveolin in MCF-7 and BT-549 cells. To confirm the effect of LRs on NADPH oxidase, LR fractions were isolated from the plasma membrane after treatment with MBCD. As shown in Fig. 6A and $\mathrm{B}$, Western blot analysis showed positive expression of raft marker flotillin-2 and caveolin-1 in fractions 2-4 of MCF-7 and BT-549 cells, respectively; we designated these as the raft fractions (11). gp91 phox was only distributed in the raft position, and after treatment with $\mathrm{MBCD}$, it was shifted to non-raft position in both MCF-7 and BT-549 cells (Fig. 6C).
In contrast, $\mathrm{p} 22^{\text {phox }}$ was distributed in both raft and non-raft position; however, after MBCD treatment, it shifted to the non-raft position (Fig. 6D). These results confirm that both gp91 ${ }^{\text {phox }}$ and $\mathrm{p} 22^{\text {phox }}$ are localized to the lipid rafts.

\section{Discussion}

Oxidative damage has been implicated in the aging process and in numerous clinical conditions, including cancer (21). Many epithelial cancers like breast, colon and neck cancers exhibit increased ROS production as compared to normal epithelial cells (22). The levels of intracellular ROS in cells ultimately affect cell cycle progression and cell proliferation. The first Nox protein identified was Nox2 in the 1980s, originally called gp91 phox. It is usually found in membranes with its signaling partner, $\mathrm{p} 22^{\text {phox }}$. Together, they form the complex known as flavocytochrome $b_{558}$. gp $91^{\text {phox }}$ belongs to the NADPH oxidase (Nox) family and contains the entire electron-transporting apparatus (23). The association of $\mathrm{p} 22^{\text {phox }}$ with gp91 ${ }^{\text {phox }}$ may also be essential for regulation of electron transfer in redox cycle (24), stabilization of gp91 phox $(25)$ and recruitment of cytosolic subunits (26). Despite the enormous progress in NADPH oxidase research, much remains to be understood regarding molecular mechanisms responsible for regulation of gp91 phox and $\mathrm{p} 22^{\text {phox }}$ and their compartmentalization especially in cancer cells.

For the first time, this study shows basal expression and association of lipid rafts with gp91 phox and $\mathrm{p} 22^{\text {phox }}$, the redox center components of phagocyte NADPH oxidase in breast cancer cells. We have characterized the expression of these subunits and their co-localization with lipid rafts using several independent approaches, including enzymatic assays, immunological assays and RT-PCR analysis. The novel findings of the present study are as follows: i) Expression of 
gp91 phox and $\mathrm{p} 22^{\text {phox }}$ membrane-bound subunits of NADPH oxidase; ii) association of gp91 phox and p22phox subunits with lipid rafts; and iii) regulation of gp91 ${ }^{\text {phox }}$ and $\mathrm{p} 22^{\text {phox }}$ subunits by cholesterol levels of membrane in MCF-7 (an estrogen receptor-positive breast cancer cell line) and BT-549 (an estrogen receptor-negative breast cancer cell line).

Breast cancer cells are reported to contain elevated levels of lipid rafts and to be more sensitive to cholesterol depletioninduced cell death (27). In the present study, we observed the lipid raft markers flotillin-1 in MCF-7 cells and caveolin-2 in BT549 cells. These results confirm previous reports of flotillin-2 in MCF-7 (28) and caveolin in BT-549 breast cancer cells (29). In the basal state, low levels of NADPH oxidases are constitutively expressed in cells (30); this expression can be enhanced by stimulators. The current studies show that Nox-dependent ROS production is differentially regulated in lipid rafts and non-lipid rafts (11). These studies also suggest inherent differences in the regulation of NADPH oxidase activity by lipid rafts, but the causes of such inherent differences remain to be discovered. In the present study, we demonstrate that the lipid raft-associated NADPH oxidase is critical for the formation of ROS in breast cancer cells. Our studies show that cholesterol depletion by MBCD caused a decrease in total ROS production as well as NADPH oxidase activity in MCF-7 and BT-549 cells. Similarly, extraction of cholesterol by MßCD inhibited superoxide generation in HL-60 cells (19). However, cholesterol depletion increased the ROS production in hRPT and HEK-293 cells (12). MBCD, a known disruptor of lipid rafts, also reported to rescue ROS levels in yeast and protect against oxidative stress (17). This study supports the notion that cholesterol, an important component of lipid rafts, affects basal oxidase activity and ROS production by means of stimulation or inhibition.

We also demonstrate that NADPH oxidase is the main source of ROS in MCF-7 and BT-549 cells as rotenone (mitochondrial electron transport inhibitor), oxypurinol (xanthine oxidase inhibitor) and L-NAME (nitric oxide synthase inhibitor) failed to inhibit ROS production as compared to MBCD. Recently, isoforms of NADPH oxidase (DUOXs) are also reported as the major source of ROS in epithelial breast cancer cells (31).

Cholesterol contents of cell membranes are tightly regulated. Cholesterol accumulation has been reported in various solid tumors including prostate cancer (32). Its metabolism is dysregulated in many malignancies $(33,34)$, thereby indicating a possible role of cholesterol in cancer development. One of the important findings in the present study is that treatment with $10 \mathrm{mM}$ MBCD for $24 \mathrm{~h}$ reduced membrane cholesterol levels (47.2\% in MCF-7 cells and $23.3 \%$ in BT-549 cells). However, it depleted cholesterol by $60 \%$ in mast cells (35) and $20 \%$ in arterial rings (36) in $1 \mathrm{~h}$. In addition to lipid disruption, depletion of membrane cholesterol by MBCD causes increased uterine activity in obese women (37) and also plays an important role in cardiovascular diseases (38).

Cyclodextrins, especially methylated- $\beta$-cyclodextrins, offer several advantages for drug delivery and lipid raft disruption. However, the toxic effect of $\mathrm{M} B \mathrm{CD}$ on cell viability is dependent on the final concentration and the particular cell type used. The present study revealed that MBCD affected cell viability in a concentration-dependent manner, with a significant loss of viability at $48 \mathrm{~h}$. In contrast, no loss of viability was observed for up to $144 \mathrm{~h}$ in human skin fibroblasts $(38,39)$.

NADPH oxidase-dependent superoxide generation has been found to be abnormally enhanced in several chronic diseases (40). However, extensive analysis of the expression of NADPH oxidase subunits, particularly two critical subunits gp91 ${ }^{\text {phox }}$ and $\mathrm{p} 22^{\text {phox }}$, in breast cancer cells and their regulation in lipid rafts has not yet been reported. Thus, in screening for the expression of the membrane-bound NADPH oxidase subunits gp91 phox and $\mathrm{p} 22^{\text {phox }}$ in MCF-7 and BT-549 breast cancer cells, we observed that both of these subunits could be detected by RT-PCR, but their expression was significantly $(\mathrm{p}<0.05)$ reduced in MBCD-treated cells as compared to untreated cells. The percentage of inhibition of gp91 phox and p22 phox was different in both cells lines. To our knowledge, this is the first investigation of mRNA expression of ROSgenerating Nox 2 and localization in lipid rafts in breast cancer.

Nox2- and Nox4-based NADPH oxidases appear to be the predominant contributors to oxidative stress (38). The gp91 ${ }^{\text {phox }}$ system in phagocytes has an apparent 91-kDa molecular mass due to extensive glycosylation. However, the antibody used in the present study, which is selective for unique amino acid sequences on this subunit [anti-goat gp91 phox antibody (C-15), Santa Cruz Biotechnology], detected protein with molecular mass of $55 \mathrm{kDa}$ both in MCF-7 and BT-549 cells. This $55-\mathrm{kDa}$ protein product may be due to lack of extensive glycosylation (41). It is likely that the protein subunits observed with the gp91 ${ }^{\text {phox }}$ antibody originate from differences in glycosylation and perhaps regulation through other forms of covalent bond modification (42). In other studies, antibodies for gp9 $1^{\text {phox }}$ have detected 65, 75 and $110 \mathrm{kDa}$ proteins (43-45).

Elevated levels of lipid rafts have been reported in breast cancer cells (27). Recently, expression of Nox isoforms (Nox1-5) has been reported in some breast cancer cell lines, including MCF-7 (46). Therefore, we speculated that there is an association between lipid rafts and NADPH oxidases in breast cancer cells. In the present study, one notable result is that although both gp91 phox and $\mathrm{p} 22^{\text {phox }}$ proteins were downregulated, p22 phox was much more significantly downregulated than gp91 phox by MßCD in both MCF-7 and BT-549 cells. These results indicate that $\mathrm{p} 22^{\text {phox }}$ regulates catalytic function of gp91 phox , possibly via interaction with lipid rafts. In addition, the key role of p22 phox in stabilizing catalytic subunits (47) and in the interaction of cytosolic organizer protein $\mathrm{p} 47^{\text {phox }}$ (8) has been reported.

In the present study, we also investigated the intracellular localization of gp91 phox and p22 phox in MCF-7 and BT-549 cells. Our data indicate that, gp91 ${ }^{\text {phox }}$ was co-localized with the lipid raft marker flotillin-2 on the cell surface of MCF-7 cells as well as caveolin-1 on the cell surface of BT-549 cells. Moreover, co-localization of gp91 ${ }^{\text {phox }}$ with the lipid raft marker GM1 in HL-60 cells has been reported (19). In addition, colocalization of both gp91 ${ }^{\text {phox }}$ and $\mathrm{p} 22^{\text {phox }}$ with lipid rafts has been demonstrated in hRPT cells (12).

Several studies have shown that lipid rafts serve as platforms to store proteins and to keep some proteins in the active or in the inactive state (48). In fact, several lines of study have demonstrated that the depletion of cholesterol from the plasma membrane causes disruption of rafts/caveolae and 
release of raft/caveola constituents into a non-raft/caveola membrane, which renders them non-functional $(49,50)$. Some NADPH oxidases and their components are localized to lipid rafts for activation. To provide direct evidence, we isolated lipid rafts fractions and analyzed them using Western blotting. Under basal conditions, both gp91 phox and $\mathrm{p} 22^{\text {phox }}$ are located in LRs. Disruption of lipid rafts with MBCD allowed the NADPH oxidase subunits ( $\mathrm{gp} 91^{\text {phox }}$ and $\mathrm{p} 22^{\text {phox }}$ ) to move from raft to non-raft positions in the membrane; this finding is similar to previous reports $(51,52)$. These results suggest that LRs play a pivotal role in the regulation of NADPH oxidase.

To confirm the effect of cholesterol depletion by MBCD on NADPH activity and expression, we supplemented MßCD treatment with cholesterol. This treatment almost completely reversed the inhibitory effect of MBCD in MCF-7 and BT-549 breast cancer cells. In another study, supplementation of cholesterol reversed the inhibitory effect on lipid raft-associated, EGF-induced chemotaxis in human breast cancer cells (53).

In summary, we show for the first time that NADPH oxidase is regulated through the distribution of its catalytic subunit, gp91 phox , and its stabilizing subunit, p22 $2^{\text {phox }}$, in membrane microdomains. Disruption of the lipid rafts decreases NADPH oxidase and ROS production. Therefore, the integrity of lipid rafts plays an important role in regulating NADPH oxidase in breast cancer cells. Further experiments are under progress towards determination of the functional importance of localized ROS production and the targeting mechanism of NADPH oxidase in breast cancer cells.

\section{Acknowledgments}

We thank Shellee Abraham for manuscript preparation, and Diana Meister and Sushma Jasti for manuscript review.

\section{References}

1. Kahan Z and Thurzo L: Breakthrough in breast cancer chemoprevention. Orv Hetil 144: 597-603, 2003.

2. Daudt A, Alberg AJ and Helzlsouer KJ: Epidemiology, prevention, and early detection of breast cancer. Curr Opin Oncol 8: 455-461, 1996

3. McPherson K, Steel CM and Dixon JM: ABC of breast diseases. Breast cancer-epidemiology, risk factors, and genetics. BMJ 321: 624-628, 2000

4. Dai Q, Gao YT, Shu XO, Yang G, Milne G, Cai Q, Wen W, Rothman N, Cai H, Li H, Xiang Y, Chow WH and Zheng W: Oxidative stress, obesity, and breast cancer risk: results from the Shanghai Women's Health Study. J Clin Oncol 27: 2482-2488, 2009 .

5. Sumimoto H, Ueno N, Yamasaki T, Taura M and Takeya R: Molecular mechanism underlying activation of superoxideproducing NADPH oxidases: roles for their regulatory proteins. Jpn J Infect Dis 57: S24-S25, 2004

6. Gorlach A, Brandes RP, Nguyen K, Amidi M, Dehghani F and Busse R: A gp91phox containing NADPH oxidase selectively expressed in endothelial cells is a major source of oxygen radical generation in the arterial wall. Circ Res 87: 26-32, 2000.

7. Dinauer MC, Pierce EA, Bruns GA, Curnutte JT and Orkin SH: Human neutrophil cytochrome b light chain (p22-phox). Gene structure, chromosomal location, and mutations in cytochromenegative autosomal recessive chronic granulomatous disease. J Clin Invest 86: 1729-1737, 1990.

8. Nobuhisa I, Takeya R, Ogura K, Ueno N, Kohda D, Inagaki F and Sumimoto $\mathrm{H}$ : Activation of the superoxide-producing phagocyte NADPH oxidase requires co-operation between the tandem SH3 domains of p47phox in recognition of a polyproline type II helix and an adjacent alpha-helix of p22phox. Biochem J 396: 183-192, 2006
9. Viedt C, Fei J, Krieger-Brauer HI, Brandes RP, Teupser D, Kamimura M, Katus HA and Kreuzer J: Role of p22phox in angiotensin II and platelet-derived growth factor AA induced activator protein 1 activation in vascular smooth muscle cells. J Mol Med 82: 31-38, 2004.

10. Jin S and Zhou F: Lipid raft redox signaling platforms in vascular dysfunction: features and mechanisms. Curr Atheroscler Rep 11: 220-226, 2009

11. Shao D, Segal AW and Dekker LV: Lipid rafts determine efficiency of NADPH oxidase activation in neutrophils. FEBS Lett 550: 101-106, 2003.

12. Han W, Li H, Villar VA, Pascua AM, Dajani MI, Wang X Natarajan A, Quinn MT, Felder RA, Jose PA and Yu P: Lipid rafts keep NADPH oxidase in the inactive state in human renal proximal tubule cells. Hypertension 51: 481-487, 2008.

13. Barman $\mathrm{S}$ and Nayak DP: Lipid raft disruption by cholesterol depletion enhances influenza A virus budding from MDCK cells. J Virol 81: 12169-12178, 2007.

14. Carter GC, Bernstone L, Sangani D, Bee JW, Harder T and James W: HIV entry in macrophages is dependent on intact lipid rafts. Virology 386: 192-202, 2009.

15. Ilangumaran S and Hoessli DC: Effects of cholesterol depletion by cyclodextrin on the sphingolipid microdomains of the plasma membrane. Biochem J 335 (Pt. 2): 433-440, 1998.

16. Zidovetzki $\mathrm{R}$ and Levitan I: Use of cyclodextrins to manipulate plasma membrane cholesterol content: evidence, misconceptions and control strategies. Biochim Biophys Acta 1768: 1311-1324, 2007.

17. Du W and Ayscough KR: Methyl beta-cyclodextrin reduces accumulation of reactive oxygen species and cell death in yeast. Free Radic Biol Med 46: 1478-1487, 2009.

18. Harder T, Scheiffele P, Verkade P and Simons K: Lipid domain structure of the plasma membrane revealed by patching of membrane components. J Cell Biol 141: 929-942, 1998.

19. Vilhardt F and van DB: The phagocyte NADPH oxidase depends on cholesterol-enriched membrane microdomains for assembly. EMBO J 23: 739-748, 2004.

20. Pralle A, Keller P, Florin EL, Simons K and Horber JK: Sphingolipid-cholesterol rafts diffuse as small entities in the plasma membrane of mammalian cells. J Cell Biol 148: 997-1008, 2000.

21. Droge W: Free radicals in the physiological control of cell function. Physiol Rev 82: 47-95, 2002.

22. Aykin-Burns N, Ahmad IM, Zhu Y, Oberley LW and Spitz DR: Increased levels of superoxide and $\mathrm{H}_{2} \mathrm{O}_{2}$ mediate the differential susceptibility of cancer cells versus normal cells to glucose deprivation. Biochem J 418: 29-37, 2009.

23. Minakami R and Sumimotoa H: Phagocytosis-coupled activation of the superoxide-producing phagocyte oxidase, a member of the NADPH oxidase (nox) family. Int J Hematol 84: 193-198, 2006.

24. Yu L, Quinn MT, Cross AR and Dinauer MC: Gp91(phox) is the heme binding subunit of the superoxide-generating NADPH oxidase. Proc Natl Acad Sci USA 95: 7993-7998, 1998.

25. Sumimoto H, Miyano K and Takeya R: Molecular composition and regulation of the Nox family NAD $(\mathrm{P}) \mathrm{H}$ oxidases. Biochem Biophys Res Commun 338: 677-686, 2005.

26. Sumimoto H, Kage Y, Nunoi H, Sasaki H, Nose T, Fukumaki Y, Ohno M, Minakami S and Takeshige K: Role of Src homology 3 domains in assembly and activation of the phagocyte NADPH oxidase. Proc Natl Acad Sci USA 91: 5345-5349, 1994.

27. Li YC, Park MJ, Ye SK, Kim CW and Kim YN: Elevated levels of cholesterol-rich lipid rafts in cancer cells are correlated with apoptosis sensitivity induced by cholesterol-depleting agents. Am J Pathol 168: 1107-1118, 2006.

28. Marquez DC, Chen HW, Curran EM, Welshons WV and Pietras RJ: Estrogen receptors in membrane lipid rafts and signal transduction in breast cancer. Mol Cell Endocrinol 246: 91-100, 2006.

29. Su Y, Vanderlaag K, Ireland C, Ortiz J, Grage H, Safe S and Frankel AE: 1,1-Bis(3'-indolyl)-1-(p-biphenyl)methane inhibits basal-like breast cancer growth in athymic nude mice. Breast Cancer Res 9: R56, 2007.

30. Rao PV, Maddala R, John F and Zigler JS Jr: Expression of nonphagocytic NADPH oxidase system in the ocular lens. Mol Vis 10: 112-121, 2004.

31. Ostrakhovitch EA and Li SS: NIP1/DUOXA1 expression in epithelial breast cancer cells: regulation of cell adhesion and actin dynamics. Breast Cancer Res Treat 119: 773-786, 2009.

32. Freeman MR and Solomon KR: Cholesterol and prostate cancer. J Cell Biochem 91: 54-69, 2004. 
33. Duncan RE, El-Sohemy A and Archer MC: Dietary factors and the regulation of 3-hydroxy-3-methylglutaryl coenzyme A reductase: implications for breast cancer and development. Mol Nutr Food Res 49: 93-100, 2005.

34. Duncan RE, El-Sohemy A and Archer MC: Mevalonate promotes the growth of tumors derived from human cancer cells in vivo and stimulates proliferation in vitro with enhanced cyclindependent kinase-2 activity. J Biol Chem 279: 33079-33084, 2004.

35. Sheets ED, Holowka D and Baird B: Critical role for cholesterol in Lyn-mediated tyrosine phosphorylation of FcepsilonRI and their association with detergent-resistant membranes. J Cell Biol 145: 877-887, 1999

36. Dreja K, Voldstedlund M, Vinten J, Tranum-Jensen J, Hellstrand P and Sward K: Cholesterol depletion disrupts caveolae and differentially impairs agonist-induced arterial contraction. Arterioscler Thromb Vasc Biol 22: 1267-1272, 2002.

37. Smith RD, Babiychuk EB, Noble K, Draeger A and Wray S: Increased cholesterol decreases uterine activity: functional effects of cholesterol alteration in pregnant rat myometrium. Am J Physiol Cell Physiol 288: C982-C988, 2005

38. Gould AL, Davies GM, Alemao E, Yin DD and Cook JR: Cholesterol reduction yields clinical benefits: meta-analysis including recent trials. Clin Ther 29: 778-794, 2007.

39. Pfitzner I, Francz PI and Biesalski HK: Carotenoid:methyl-betacyclodextrin formulations: an improved method for supplementation of cultured cells. Biochim Biophys Acta 1474: 163-168, 2000

40. Davalos A, de la PG, Sanchez-Martin CC, Teresa GM, Bartolome B and Lasuncion MA: Effects of red grape juice polyphenols in NADPH oxidase subunit expression in human neutrophils and mononuclear blood cells. Br J Nutr 1-11, 2009.

41. Murillo I and Henderson LM: Expression of gp91phox/Nox2 in COS-7 cells: cellular localization of the protein and the detection of outward proton currents. Biochem J 385: 649-657, 2005.

42. Gupte SA, Kaminski PM, Floyd B, Agarwal R, Ali N, Ahmad M, Edwards J and Wolin MS: Cytosolic NADPH may regulate differences in basal Nox oxidase-derived superoxide generation in bovine coronary and pulmonary arteries. Am J Physiol Heart Circ Physiol 288: H13-H21, 2005.

43. Archer SL, Reeve HL, Michelakis E, Puttagunta L, Waite R, Nelson DP, Dinauer MC and Weir EK: O2 sensing is preserved in mice lacking the gp91phox subunit of NADPH oxidase. Proc Natl Acad Sci USA 96: 7944-7949, 1999.
44. Li JM, Gall NP, Grieve DJ, Chen M and Shah AM: Activation of NADPH oxidase during progression of cardiac hypertrophy to failure. Hypertension 40: 477-484, 2002.

45. MacCarthy PA, Grieve DJ, Li JM, Dunster C, Kelly FJ and Shah AM: Impaired endothelial regulation of ventricular relaxation in cardiac hypertrophy: role of reactive oxygen species and NADPH oxidase. Circulation 104: 2967-2974, 2001.

46. Juhasz A, Ge Y, Markel S, Chiu A, Matsumoto L, van BJ, Roy K and Doroshow JH: Expression of NADPH oxidase homologues and accessory genes in human cancer cell lines, tumours and adjacent normal tissues. Free Radic Res 43: 523-532, 2009.

47. Kawahara T, Ritsick D, Cheng G and Lambeth JD: Point mutations in the proline-rich region of p22phox are dominant inhibitors of Nox1- and Nox2-dependent reactive oxygen generation. J Biol Chem 280: 31859-31869, 2005.

48. Allen JA, Halverson-Tamboli RA and Rasenick MM: Lipid raft microdomains and neurotransmitter signalling. Nat Rev Neurosci 8: 128-140, 2007.

49. London $E$ and Brown DA: Insolubility of lipids in triton $X-100$ : physical origin and relationship to sphingolipid/cholesterol membrane domains (rafts). Biochim Biophys Acta 1508: 182-195, 2000.

50. Scheel-Toellner D, Wang K, Singh R, Majeed S, Raza K, Curnow SJ, Salmon M and Lord JM: The death-inducing signalling complex is recruited to lipid rafts in Fas-induced apoptosis. Biochem Biophys Res Commun 297: 876-879, 2002.

51. Li H, Han W, Villar VA, Keever LB, Lu Q, Hopfer U, Quinn MT, Felder RA, Jose PA and Yu P: D1-like receptors regulate $\mathrm{NADPH}$ oxidase activity and subunit expression in lipid raft microdomains of renal proximal tubule cells. Hypertension 53: 1054-1061, 2009

52. Zhang AY, Yi F, Zhang G, Gulbins E and Li PL: Lipid raft clustering and redox signaling platform formation in coronary arterial endothelial cells. Hypertension 47: 74-80, 2006

53. Liu Y, Sun R, Wan W, Wang J, Oppenheim JJ, Chen L and Zhang N: The involvement of lipid rafts in epidermal growth factor-induced chemotaxis of breast cancer cells. Mol Membr Biol 24: 91-101, 2007. 